\title{
Calcium, phosphorus, and magnesium concentrations in plasma during first week of life and their relation to type of milk feed
}

\author{
G. T. LEALMAN, R. W. LOGAN, J. H. HUTCHISON, M. M. KERR, A. M. FULTON, and \\ C. A. BROWN \\ From the University Department of Child Health, the Department of Biochemistry, Queen Mother's \\ Hospital, Glasgow, and the Computer Applications Unit, Greater Glasgow Health Board
}

\begin{abstract}
Lealman, G. T., Logan, R. W., Hutchison, J. H., Kerr, M. M., Fulton, A. M., and Brown, C. A. (1976). Archives of Disease in Childhood, 51, 377. Calcium, phosphorus, and magnesium concentrations in plasma during first week of life and their relation to type of milk feed. Serial changes in plasma levels of calcium, phosphorus, magnesium, alkaline phosphatase, and total proteins have been investigated in 138 healthy, term Caucasian infants. Blood samples were obtained for each infant from cord blood and on day 1 and day 6 . The infants were studied in three groups according to whether they were breast fed, received 'Ostermilk No. 1' or 'Cow and Gate V' formulas.

Levels of calcium, phosphorus, magnesium, alkaline phosphatase, and total proteins did not differ between the groups at birth or on day 1. By day 6 calcium levels were higher and phosphorus levels lower in the breast-fed infants compared with either of the artificially-fed groups. Phosphorus levels were lower in the V Formula group compared with the Ostermilk group but the mean calcium levels of these two groups did not differ significantly. However, only $2 \cdot 8 \%$ of the $\mathrm{V}$ Formula group developed hypocalcaemia compared with $18 \cdot 2 \%$ of the Ostermilk group. The only infant developing clinical tetany belonged to the group fed Ostermilk. Evidence is also given which suggests that those infants with low calcium levels on day 1 who were fed the high-solute milk tended to show a fall in calcium by day 6 . This did not apply to the two other groups. It is concluded that the use of adapted cows' milk preparations for infant feeding should lead to a reduction in the incidence of neonatal tetany.
\end{abstract}

When considering the introduction of a 'humanized' cows' milk preparation for the routine feeding of the newborn at this hospital, it became apparent that there was a need to redefine normal values for various biochemical parameters. It was also considered important to establish whether the change in feeding would lead to a reduction in the incidence of neonatal tetany. This paper reports the results of this aspect of the trial.

The study was designed to assess changes in plasma calcium, inorganic phosphorus, magnesium, total protein, and alkaline phosphatase during the first 6 days of life in three groups of healthy term

Received 29 August 1975. infants. The first comprised those fed on an adapted cows' milk preparation, Cow and Gate V Formula; the second group were fed Ostermilk No. 1; and the third group were breast-fed.

\section{Methods}

The trial was carried out at the Queen Mother's Hospital, Glasgow, between November 1973 and July 1974. A total of 138 Caucasian babies were studied. Infants were admitted to the trial only if cord blood was obtained at delivery and the plasma was separated within one hour. All had a gestational age of between 37 and 41 weeks, and the minimum acceptable birthweight was taken as $2500 \mathrm{~g}$. All were singleton births. Babies requiring active resuscitation at birth were excluded as 
were any who later developed any problem other than tetany.

The milks were prepared in the hospital milk kitchen from the powder preparation according to the manufacturers' directions. The trial was conducted in one wing of the hospital and the type of milk given to any baby was determined by the month of admission ( $V$ Formula and Ostermilk No. 1 being used on alternate months) unless the mother wished to breast feed. Such mothers were helped in the usual way and breast-fed babies were admitted continuously throughout the course of the trial. Breast-fed babies were allowed complementary and supplementary feeds as was considered necessary by the nursing staff, but any who received $>500 \mathrm{ml}$ of cows' milk over the first 6 days of life were excluded from the trial.

From the age of about 12 hours when the first feed of dextrose water was given, babies were fed 4-hourly. Bottle-fed babies were offered $30 \mathrm{ml}$ of milk at each feed on the first day, $60 \mathrm{ml}$ on the second, $90 \mathrm{ml}$ on the third, and by the fourth day they were being offered $120 \mathrm{ml}$ at each feed. The total volume of milk taken was recorded, as was the infant's weight on day 6 . Random samples of $\mathrm{V}$ Formula milk and Ostermilk No. 1 were taken and analysed (Table I). The calcium and phosphorus content of transitional human milk is taken from Barltrop and Hillier (1974a).

\section{TABLE I}

Calcium and phosphorus contents of milks used ( $\mathrm{mg} / 100 \mathrm{ml}$ milk). Data for transitional breast milk from Barltrop and Hillier (1974a)

\begin{tabular}{l|c|c|c}
\hline & Ostermilk No. 1 & V Formula & Breast milk \\
\hline Calcium & 81 & 68 & $28 \cdot 0 \pm 6 \cdot 7$ \\
Phosphorus & 64 & 50 & $15 \cdot 5 \pm 4 \cdot 6$ \\
Ca/P ratio & $1 \cdot 3$ & $1 \cdot 4$ & $2 \cdot 0 \pm 0 \cdot 5$ \\
& & & \\
\hline
\end{tabular}

Three blood samples were obtained from each subject. Cord blood was taken at birth and on day 1 (12-36 hours of age) and day $6,2 \mathrm{ml}$ of blood were taken by heel prick into lithium-beparin and flouride tubes. Blood samples were taken in the hour preceding a feed. The heparinized plasma was separated within one hour and any sample in which there was more than minimal haemolysis was rejected. Parental permission for inclusion in the study was obtained in all cases.

Determination of plasma calcium, phosphorus, and protein was accomplished using an SMA 12 Micro AutoAnalyser as described by Logan and Tweedie (1973). Plasma magnesium was determined by atomic absorption spectrophotometry according to the method of Stewart, Hutchinson, and Fleming (1963), and blood glucose was measured using a Beckman glucose analyser. Plasma alkaline phosphatase was estimated in KingArmstrong units by an automated method yielding results indistinguishable from the manual procedure of Kind and King (1954).

\section{Results}

138 infants were admitted to the trial and of these 45 were breast fed, 36 were fed on V Formula milk, and 55 received Ostermilk No. 1. Data from both sexes were combined for all statistical analyses. The mean birthweights of the three groups did not differ significantly, and the mean change in weight by day 6 did not differ significantly in any group $(P>0 \cdot 20)$. Table II gives the mean birthweights and the weights on day 6 , according to the feeding regimen.

The mean levels of alkaline phosphatase and total proteins are shown in Table III. In the case of the alkaline phosphatase it can be seen that the ranges in cord blood are very wide in the groups subsequently fed Ostermilk No. 1 and Cow and Gate V Formula. This was due entirely to isolated, unexplained high values in the two groups. By day 6 , however, there was no significant difference in the alkaline phosphatase results in any of the groups $(P>0 \cdot 20)$. In the case of protein concentration, there was no significant difference between the three groups in the results in cord blood ( $P>0 \cdot 20)$, but by day 6 the concentration in the group fed Ostermilk No. 1 was higher than in that fed V Formula $(P<0 \cdot 01)$.

Cord blood. The mean values of plasma calcium, inorganic phosphorus, and magnesium in cord blood did not differ significantly among the three groups $(P>0 \cdot 20)$. Table IV gives the mean levels, standard deviations, and ranges for plasma calcium, phosphorus, and magnesium in cord blood according to feeding regimen.

Day 1. There was also no significant difference $(P>0 \cdot 20)$ between the mean plasma levels of

\section{TABLE II}

Mean weights (kg) of the 3 groups of infants at birth and on day 6

\begin{tabular}{l|c|c}
\hline & Birth & Day 6 \\
\hline $\begin{array}{l}\text { Ostermilk No. 1 } \\
\text { Mean }\end{array}$ & $3 \cdot 44$ & $3 \cdot 44$ \\
SD & $0 \cdot 45$ & $0 \cdot 45$ \\
Range & $2 \cdot 80-4 \cdot 85$ & $2 \cdot 69-4 \cdot 70$ \\
V Formula & & \\
Mean & $3 \cdot 37$ & $3 \cdot 31$ \\
SD & $0 \cdot 44$ & $0 \cdot 43$ \\
Range & $2 \cdot 57-4 \cdot 41$ & $2 \cdot 54-4 \cdot 44$ \\
Breast milk & & \\
Mean & $3 \cdot 53$ & $3 \cdot 42$ \\
SD & $0 \cdot 42$ & $0 \cdot 40$ \\
Range & $2 \cdot 75-4 \cdot 40$ & $2 \cdot 62-4 \cdot 42$ \\
& & \\
\hline
\end{tabular}


TABLE III

Alkaline phosphatase (KA units/100 $\mathrm{ml})$ and total proteins $(\mathrm{g} / 100 \mathrm{ml})$

\begin{tabular}{|c|c|c|c|c|c|c|}
\hline & \multicolumn{3}{|c|}{ Alkaline phosphatase } & \multicolumn{3}{|c|}{ Total proteins } \\
\hline & Cord blood & Day 1 & Day 6 & Cord blood & Day 1 & Day 6 \\
\hline $\begin{array}{l}\text { V Formula } \\
\text { No. } \\
\text { Mean } \\
\text { SD } \\
\text { Range }\end{array}$ & $\begin{array}{l}36 \\
15 \cdot 5 \\
10 \cdot 3 \\
6 \cdot 0-71\end{array}$ & $\begin{array}{c}35 \\
15 \cdot 3 \\
4 \cdot 8 \\
6 \cdot 0-29\end{array}$ & $\begin{array}{c}36 \\
14 \cdot 3 \\
4 \cdot 1 \\
5 \cdot 5-25 \cdot 5\end{array}$ & $\begin{array}{c}37 \\
5 \cdot 94 \\
0 \cdot 62 \\
4 \cdot 3-7 \cdot 3\end{array}$ & $\begin{array}{c}37 \\
5 \cdot 69 \\
0 \cdot 40 \\
4 \cdot 8-6 \cdot 4\end{array}$ & $\begin{array}{c}36 \\
5 \cdot 80 \\
0 \cdot 43 \\
4 \cdot 7-6 \cdot 9\end{array}$ \\
\hline $\begin{array}{l}\text { Breast milk } \\
\text { No. } \\
\text { Mean } \\
\text { SD } \\
\text { Range }\end{array}$ & $\begin{array}{c}44 \\
13 \cdot 4 \\
4 \cdot 2 \\
4 \cdot 5-26\end{array}$ & $\begin{array}{c}41 \\
13 \cdot 2 \\
3 \cdot 6 \\
4 \cdot 5-23 \cdot 5\end{array}$ & $\begin{array}{c}42 \\
14 \cdot 6 \\
3 \cdot 8 \\
7 \cdot 5-22 \cdot 5\end{array}$ & $\begin{array}{c}44 \\
6 \cdot 06 \\
0 \cdot 55 \\
4 \cdot 8-7 \cdot 1\end{array}$ & $\begin{array}{c}43 \\
5 \cdot 97 \\
0 \cdot 43 \\
5 \cdot 2-7 \cdot 0\end{array}$ & $\begin{array}{c}45 \\
5 \cdot 94 \\
0 \cdot 41 \\
5 \cdot 0-7 \cdot 0\end{array}$ \\
\hline
\end{tabular}

TABLE IV

Cord blood-plasma calcium, phosphorus, and magnesium concentrations, according to feeding regimen

\begin{tabular}{|c|c|c|c|}
\hline & $\begin{array}{l}\text { Calcium } \\
(\mathrm{mEq} / \mathrm{l})\end{array}$ & $\begin{array}{l}\text { Phosphorus } \\
(\mathrm{mg} / 100 \mathrm{ml})\end{array}$ & $\underset{(\mathrm{mEq} / \mathbf{l})}{\text { Magnesium }}$ \\
\hline $\begin{array}{l}\text { Ostermilk No .1 } \\
\text { No. } \\
\text { Mean } \\
\text { SD } \\
\text { Range }\end{array}$ & $\begin{array}{c}51 \\
5 \cdot 45 \\
0 \cdot 46 \\
4 \cdot 20-7 \cdot 00\end{array}$ & $\begin{array}{c}51 \\
5 \cdot 31 \\
0 \cdot 79 \\
3 \cdot 50-7 \cdot 50\end{array}$ & $\begin{array}{c}48 \\
1 \cdot 61 \\
0 \cdot 21 \\
0 \cdot 91-2 \cdot 24\end{array}$ \\
\hline $\begin{array}{l}\text { Breat milk } \\
\text { No. } \\
\text { Mean } \\
\text { SD } \\
\text { Range }\end{array}$ & $\begin{array}{c}44 \\
5 \cdot 57 \\
0 \cdot 33 \\
5 \cdot 00-6 \cdot 40\end{array}$ & $\begin{array}{c}44 \\
5 \cdot 33 \\
0 \cdot 87 \\
3 \cdot 00-7 \cdot 00\end{array}$ & $\begin{array}{c}41 \\
1 \cdot 60 \\
0 \cdot 22 \\
1 \cdot 14-2 \cdot 21\end{array}$ \\
\hline
\end{tabular}

calcium, phosphorus, and magnesium in the three groups of infants on day 1 . In all except 3 babies there was a fall in plasma calcium on day 1 compared with the cord blood level. In the majority of cases the concentration of plasma inorganic phosphorus rose between birth and day 1. There was no consistent change in the magnesium concentrations. The data for day 1 is summarized in Table V.

Day 6. Table VI shows the mean values, standard deviations, and ranges of plasma calcium, inorganic phosphorus, and magnesium on day 6 according to the feeding regimen. The distribution of the individual values of plasma calcium, phosphorus, and magnesium according to feeding regimen are shown in Figs. 1, 2, and 3, respectively. One infant in the trial with a plasma calcium of 2.5 $\mathrm{mEq} / \mathrm{l}$ who was fed Ostermilk No. 1 exhibited clinical tetany on day 6. Plasma phosphorus in this infant was $8.3 \mathrm{mg} / 100 \mathrm{ml}$ and magnesium $1 \cdot 16$ $\mathrm{mEq} / \mathrm{l}$.

By day 6 the mean plasma calcium concentration of the breast-fed group was higher than that found 
TABLE V

Day 1-plasma calcium, phosphorus, and magnesium concentrations, according to feeding regimen

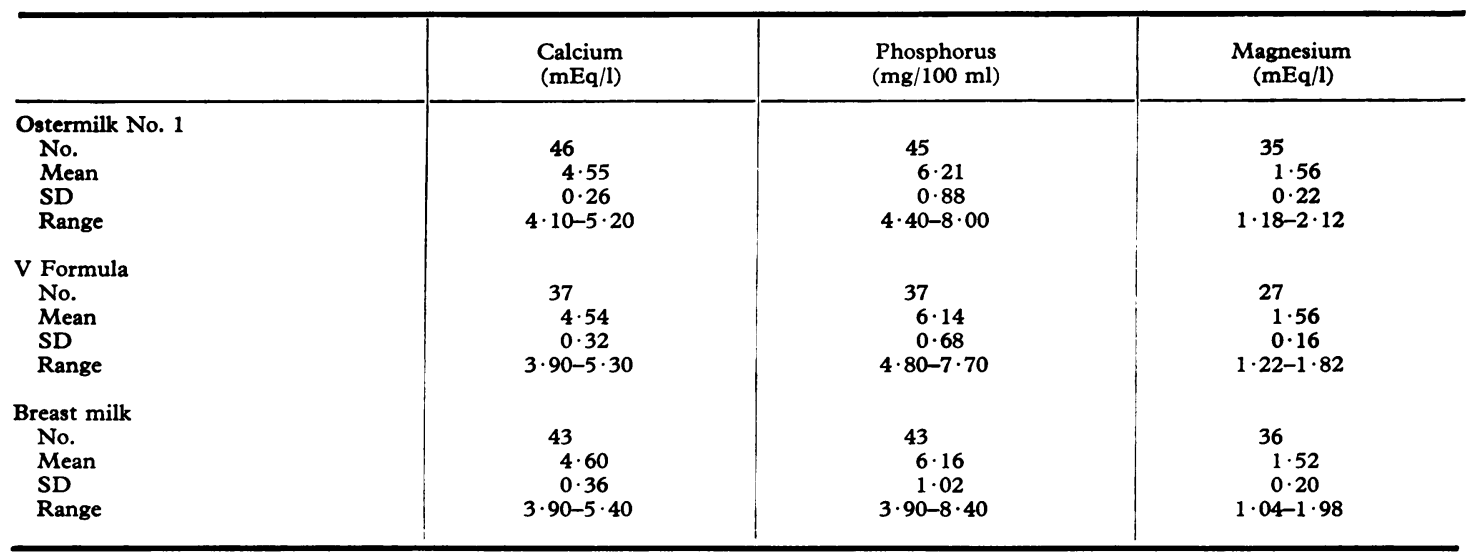

TABLE VI

Day 6-plasma calcium, phosphorus, and magnesium concentrations, according to feeding regimen

\begin{tabular}{|c|c|c|c|}
\hline & $\begin{array}{l}\text { Calcium } \\
(\mathrm{mEq} / \mathrm{l})\end{array}$ & $\begin{array}{l}\text { Phosphorus } \\
(\mathrm{mg} / 100 \mathrm{ml})\end{array}$ & $\underset{(\mathrm{mEq} / \mathrm{l})}{\text { Magnesium }}$ \\
\hline $\begin{array}{l}\text { Ostermilk no. } 1 \\
\text { No. } \\
\text { Mean } \\
\text { SD } \\
\text { Range }\end{array}$ & $\begin{array}{c}55 \\
4 \cdot 52 \\
0 \cdot 78 \\
2 \cdot 50-5 \cdot 50\end{array}$ & $\begin{array}{c}55 \\
8 \cdot 56 \\
1 \cdot 11 \\
6 \cdot 50-12 \cdot 0\end{array}$ & $\begin{array}{c}43 \\
1 \cdot 51 \\
0 \cdot 24 \\
1 \cdot 12-2 \cdot 08\end{array}$ \\
\hline $\begin{array}{l}\text { V Formula } \\
\text { No. } \\
\text { Mean } \\
\text { SD } \\
\text { Range }\end{array}$ & $\begin{array}{c}36 \\
4 \cdot 69 \\
0 \cdot 49 \\
3 \cdot 50-5 \cdot 60\end{array}$ & $\begin{array}{c}36 \\
7 \cdot 86 \\
0 \cdot 89 \\
6 \cdot 00-9 \cdot 40\end{array}$ & $\begin{array}{c}34 \\
1 \cdot 59 \\
0 \cdot 28 \\
0 \cdot 95-2 \cdot 20\end{array}$ \\
\hline $\begin{array}{l}\text { Breast milk } \\
\text { No. } \\
\text { Mean } \\
\text { SD } \\
\text { Range }\end{array}$ & $\begin{array}{c}45 \\
5 \cdot 09 \\
0 \cdot 41 \\
3 \cdot 80-5 \cdot 70\end{array}$ & $\begin{array}{c}45 \\
6 \cdot 35 \\
0 \cdot 75 \\
5 \cdot 00-8 \cdot 40\end{array}$ & $\begin{array}{c}35 \\
1 \cdot 68 \\
0 \cdot 25 \\
1 \cdot 33-2 \cdot 46\end{array}$ \\
\hline
\end{tabular}

in either of the artificially fed groups $(P<<0.01)$. The mean value for calcium did not differ significantly between the two artificially fed groups of infants $(P>0 \cdot 20)$. Plasma phosphorus concentrations were lowest in the breast-fed group, and the mean value was lower than that found in either of the artificially-fed groups $(P<<0 \cdot 01)$. The mean plasma phosphorus concentration in the infants fed V Formula was lower than that in the group receiving Ostermilk No. $1(P<0 \cdot 01)$.

Plasma magnesium concentrations were highest in the breast-fed infants. The mean value was higher than that of the infants fed Ostermilk No. $1(\mathrm{P}<$
$0 \cdot 01)$ but was not greater than the mean magnesium result in the V Formula group $(0 \cdot 20>P>0 \cdot 10)$. Though the mean value in the $\mathrm{V}$ Formula group was higher than that of the Ostermilk No. 1 group, this difference was not significant $(0 \cdot 20>P>0 \cdot 10)$.

Paired day 1 and day 6 data. The changes in plasma calcium in individual infants which occurred between day 1 and day 6 are shown in Fig. 4. The majority of breast-fed infants ( 35 out of 42 ) had a rise in plasma calcium in this period. The mean rise was $0.50 \mathrm{mEq} / 1$ (SD 0.49). Of the 35 infants fed with $\mathrm{V}$ Formula milk, there was a rise in plasma 


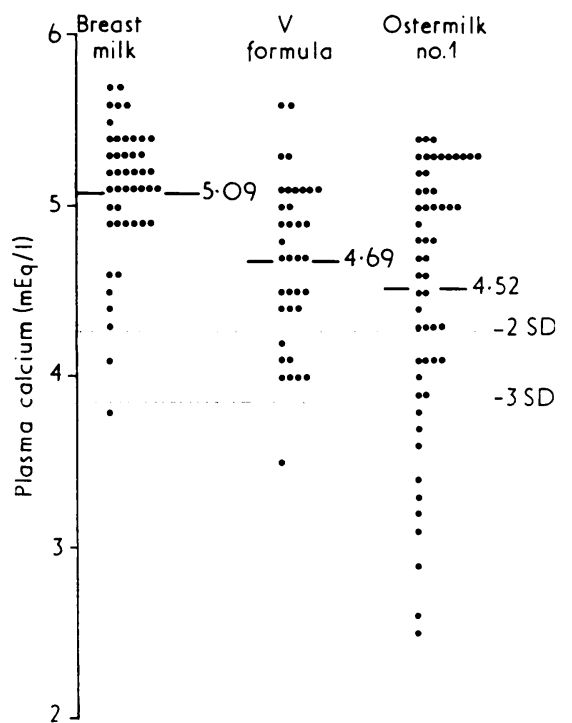

FIG. 1.-Plasma calcium levels on day 6 grouped according to feeding regimen. Mean value for each group is shown; broken lines represent 2 and $3 S D$ below the mean for the breast-fed group.

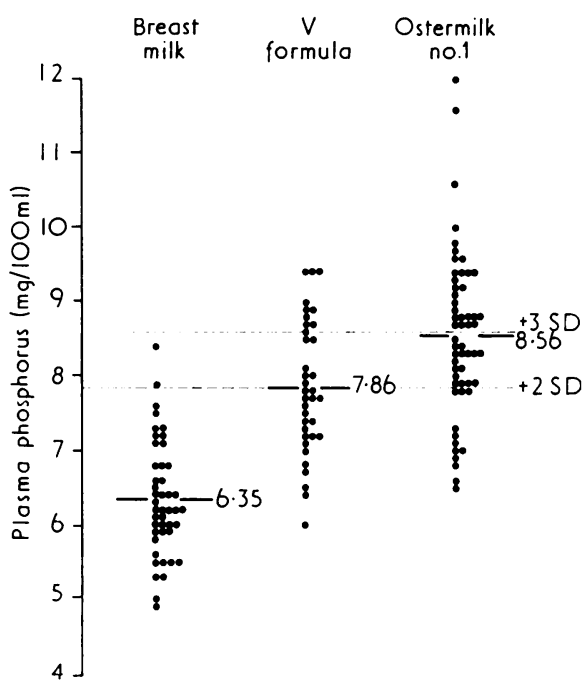

FIG. 2.-Plasma phosphorus levels on day 6 grouped according to feeding regimen. Mean value for each group is shown, broken lines represent 2 and $3 S D$ above the mean for the breast-fed group.

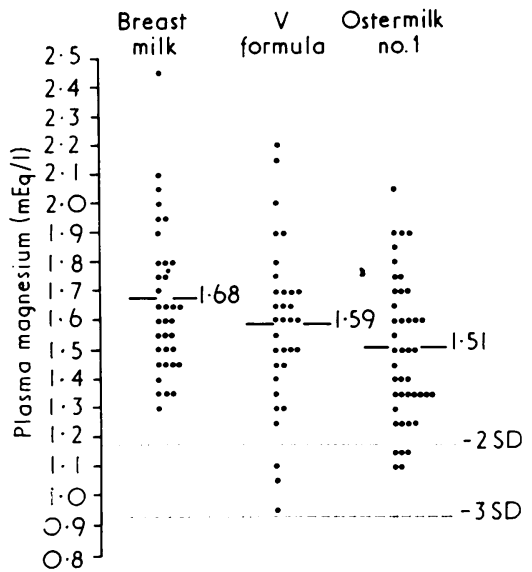

FIG. 3.-Plasma magnesium levels on day 6 grouped according to feeding regimen. Mean value for each group is shown; broken lines represent 2 and 3 SD below the mean for the breast-fed group.

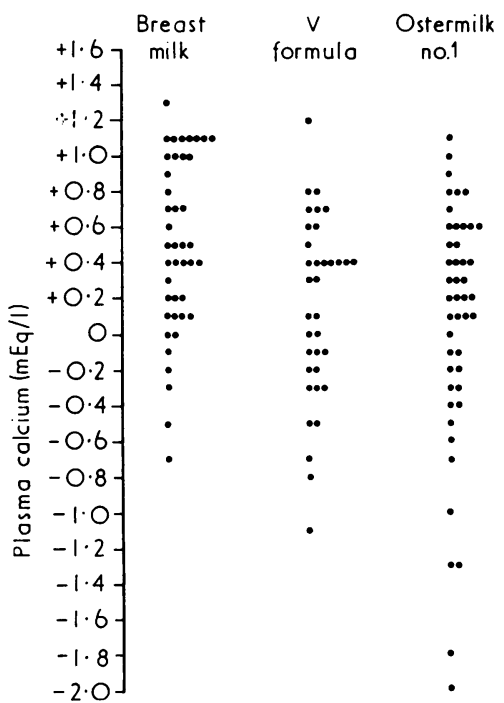

FIG. 4.-Change in plasma calcium occurring between day 1 and day 6 in individual infants grouped according to feeding regimen.

calcium in 20 , with a mean rise of $0.12 \mathrm{mEq} / 1$ (SD 0.50). The largest falls in plasma calcium in this period occurred in the babies fed with Ostermilk No. 1, but 29 out of the 46 infants experienced a rise in plasma calcium. There was a mean fall of $0.02 \mathrm{mEq} / 1$ (SD 0.70 ). Regression analysis of day 1 and day 6 calcium values showed a correlation between calcium levels on day 1 and on 
day 6. Fig. 5 illustrates this analysis according to feeding regimen. The central rectangular area represents the range of values for plasma calcium obtained during the study.

The changes in plasma phosphorus levels between day 1 and day 6 are shown in Fig. 6. An

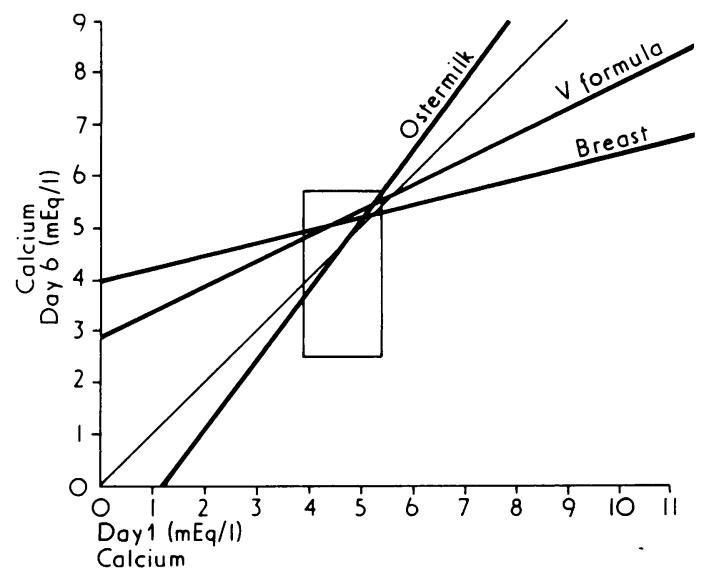

Fig. 5.-Regression lines obtained by plotting day 6 calcium values against those on day 1 according to feeding regimen. The $45^{\circ}$ slope line is shown; the rectangle encloses the area within which all calcium values on day 1 and day 6 were obtained.

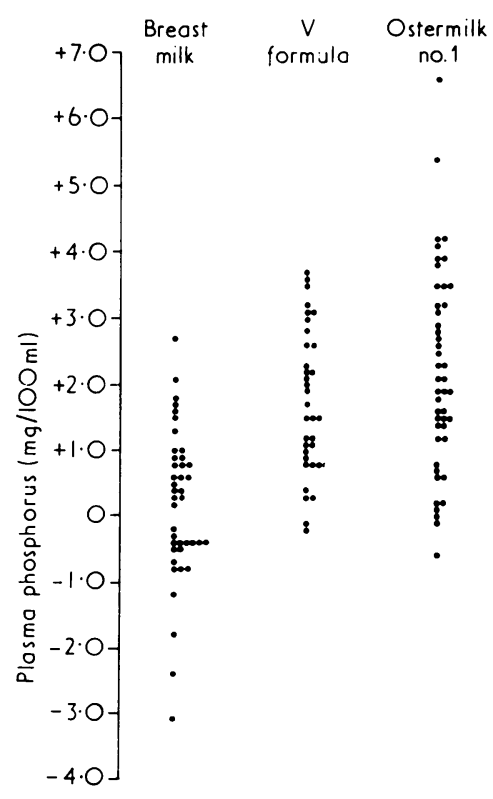

FIG. 6.-Change in plasma phosphorus occurring between day 1 and day 6 in individual infants grouped according to feeding regimen. increase in plasma phosphorus occurred in 26 of the 41 babies who were breast fed. The mean increment was $0.2 \mathrm{mg} / 100 \mathrm{ml}$. Virtually all the artificially-fed babies experienced a rise in plasma phosphorus during this time, a fall occurring in only 2 infants from each group. The mean increment in plasma phosphorus was $1.7 \mathrm{mg} / 100 \mathrm{ml}$ in the $\mathrm{V}$ Formula group and $2 \cdot 2 \mathrm{mg} / 100 \mathrm{ml}$ in the Ostermilk No. 1 group.

The changes in plasma magnesium concentration from day 1 to day 6 are shown in Fig. 7. There was an increase in magnesium values in the majority (23 out of 30) of breast-fed babies. The mean increment was $0.18 \mathrm{mEq} / 1$. Only 8 of 24 infants receiving $\mathrm{V}$ Formula milk showed an increase in magnesium over this period and the largest fall in magnesium in any baby occurred in this group. The magnesium concentration in this baby fell $0.85 \mathrm{mEq} / \mathrm{l}$ from day 1 to day 6 , and on day 6 the magnesium level was $0.9 \mathrm{mEq} / 1$ calcium 3.5 $\mathrm{mEq} / \mathrm{l}$, and phosphorus $8.7 \mathrm{mg} / 100 \mathrm{ml}$. The baby was asymptomatic. The mean fall in magnesium in the $\mathrm{V}$ Formula group was $0.03 \mathrm{mEq} / \mathrm{l}$ and $0.08 \mathrm{mEq} / 1$ in the Ostermilk No. 1 group.

\section{Discussion}

An important factor in the pathogenesis of neonatal tetany is considered to be the high phosphorus intake of artifically-fed infants (Gardner, 1953; Snodgrass et al., 1973). Because of this it has been recommended that all cow's milk pro-

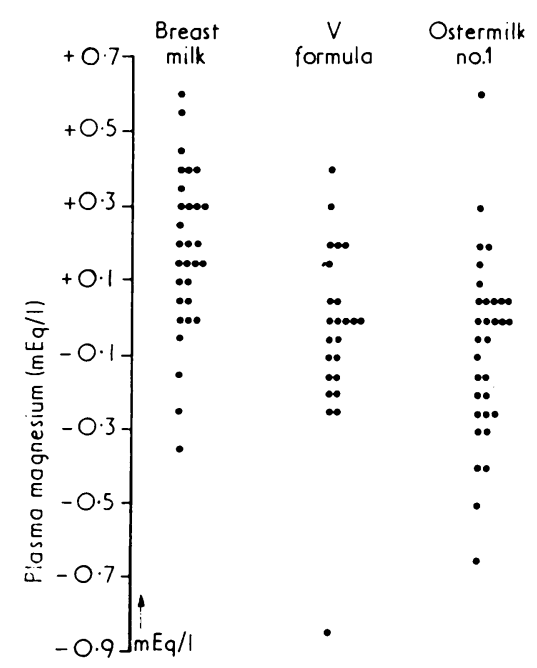

FIG. 7.-Change in plasma magnesium occurring between day 1 and day 6 in individual infants grouped according to feeding regimen. 
ducts for infant feeding should be partially demineralized (Oppé and Redstone, 1968). In addition to the phosphorus content, the calcium/ phosphorus ratio of milk foods may also be of importance (Barltrop and Oppé, 1970). In common with similar adapted milk food preparations, Cow and Gate V Formula has reduced levels of both calcium and phosphorus but has a calcium/ phosphorus ratio similar to that of unadapted cows' milk considerably below that of breast milk (Table I). V Formula also differs from Ostermilk No. 1 in having most of the butterfat replaced by vegetable oils. This adjustment to the fatty acid structure of the milk can be expected to improve the absorption of the fat (Southgate et al., 1969), but whether this results in an improved absorption of calcium is not clear (Snodgrass et al., 1973; Southgate et al., 1969; Barltrop and Oppé, 1973).

The three groups of infants had similar cord blood levels of calcium, phosphorus, magnesium, alkaline phosphatase, and total proteins, and these levels did not differ significantly between the groups at 12-36 hours of age. The fall in plasma calcium between birth and one day of age which has previously been reported (Snodgrass et al., 1973; Acharya and Payne, 1965) was confirmed, but this was not invariable. A rise in plasma calcium during this interval occurred in 3 infants, the maximum rise being $0.5 \mathrm{mEq} / \mathrm{l}$.

By day 6 the concentration of calcium was higher and of phosphorus significantly lower in the breast-fed infants when compared with either of the two groups of artificially-fed infants. These findings are similar to those of Barltrop and Hillier (1974b) using V Formula and of Snodgrass et al. (1973) using SMA. Like Snodgrass et al. (1973), we were unable to confirm the findings of Oppé and Redstone (1968) who found no significant difference between the adapted milk and breast milk in respect of the mean calcium concentration on day 6 . The artificially fed groups differed by day 6 in that the mean level of phosphorus of the V Formula group was lower than that of the infants fed Ostermilk No. 1. Despite this lower mean phosphorus level, the mean plasma calcium of these infants was not higher than that of the Ostermilk group. The lower levels of total plasma proteins found in the $\mathrm{V}$ Formula group would tend to reduce any difference between the two groups.

Despite this absence of any significant difference between the mean day 6 plasma calcium levels of the two artificially-fed groups of infants, the only case of tetany occurred in a baby receiving the high solute milk. Also on defining the lower limit of normal for plasma calcium as 3 SD below the mean of the breast-fed group $(3.85 \mathrm{mEq} / \mathrm{l})$, it is found that one infant $(2 \cdot 8 \%)$ of the V Formula group and 10 infants $(18 \cdot 2 \%)$ of the Ostermilk group had calcium levels below this. One infant of the breastfed group had a day 6 calcium level of $3.80 \mathrm{mEq} / 1$. If the upper limit of normal for plasma phosphorus is defined in a similar way (mean breast fed $+3 \mathrm{SD}$ ), 27 infants of the Ostermilk group (49\%) had phosphorus levels above this level of $8 \cdot 60 \mathrm{mg} / 100$ $\mathrm{ml}$ on day 6 , and 9 infants (25\%) of the V Formula group. No infants had a day 6 magnesium level which was lower than the mean of the breast fed group by more than 3 SDs.

If the plasma calcium levels of individual infants on day 6 are considered (Fig. 1) it is apparent that many of the artificially-fed infants did have plasma calcium levels similar to those of the breast-fed babies. This invokes the question as to whether those infants who subsequently become hypocalcaemic when fed with a high solute milk differ at birth or on the first day from those infants who do not subsequently become hypocalcaemic. The cord blood and day 1 results of the Ostermilk group were divided into two groups according to whether hypocalcaemia subsequently developed (mean breast fed-3 SD). The mean calcium phosphorus, and alkaline phosphatase levels of these two groups so formed did not differ significantly. This agrees with the work of Watney et al. (1971).

However, analysis of the changes in plasma calcium which occurred between days 1 and 6 showed the general relation between calcium levels on day 1 and day 6 which has been reported previously by Snodgrass et al. (1973). When the three feeding regimens are considered separately, it is found that the gradient of the regression line obtained for Ostermilk suggests that those infants with low values on day 1 tended to show a fall in calcium level by day 6 , whereas those with higher values on day 1 may actually show an increase in calcium by day 6 . This relation was not found to hold for the V Formula and breast-fed groups. It is recognized that with the individual plasma calcium values being grouped within quite narrow limits, the gradient of the line could be altered without much change in the correlation coefficient.

While our results do not provide conclusive evidence that the incidence of neonatal tetany will be reduced by the use of adapted cow's milk preparations for infant feeding, they do suggest that this desired effect will occur with the use of such milks. The lower plasma phosphorus levels of the infants receiving the adapted milk along with the lower incidence of hypocalcaemia are of particular significance. 
We thank the staff of the Labour Ward, West Wing, and Paediatric Department of the Queen Mother's Hospital for help during the course of the trial, in particular, Miss S. Finlayson, Miss J. Young, and Miss M. Turner; and also thank Cow and Gate for providing the $\mathrm{V}$ Formula used in the study.

\section{REFERENCES}

Acharya, P. T., and Payne, W. W. (1965). Blood chemistry of normal full-term infants in the first $\mathbf{4 8}$ hours of life. Archives of Disease in Childhood, 40, 430.

Barltrop, D., and Hillier, R. (1974a). Calcium and phosphorus content of transitional and mature human milk. Acta Paediatrica Scandinavica, 63, 347.

Barltrop, D., and Hillier, R. (1974b). Clinical evaluation of a new milk-food formula for infants. Practitioner, 212, 129.

Barltrop, D., and Oppé, T. E. (1970). Dietary factors in neonatal calcium homeostasis. Lancet, 2, 1333.

Barltrop, D., and Oppé. T. E. (1973). Absorption of fat and calcium by low birthweight infants from milks containing butterfat and olive oil. Archives of Disease in Childhood, 48, 496.

Gardner, L. I. (1953). Effect of calcium and phosphate content of the diet of newborn infants. Calcium and Phosphorus Metabolism. Report of the Fourth $M$ and $R$ Pediatric Research Conference, p. 210. $\mathrm{M}$ and $\mathrm{R}$ Laboratories, Columbus, Ohio.
Kind, P. R. N., and King, E. J. (1954). Estimation of plasma phosphatase by determination of hydrolysed phenol aminoantipyrine. Fournal of Clinical Pathology, 7, 322.

Logan, R. W., and Tweedie, A. K. (1973). An evaluation of the SMA 12/Micro AutoAnalyser in the clinical biochemistry laboratory. Clinica Chimica Acta, 44, 73.

Oppé, T. E., and Redstone, D. (1968). Calcium and phosphorus levels in healthy newborn infants given various types of milk. Lancet, 1, 1045.

Snodgrass, G. J. A. I., Stimmler, L., Went, J., Abrams, M. E., and Will, E. J. (1973). Interrelations of plasma calcium, inorganic phosphate, magnesium, and protein over the first week of life. Archives of Disease in Childhood, 48, 279.

Southgate, D. A. T., Widdowson, E. M., Smits, B. J., Cooke, W. T., Walker, C. H. M., and Mathers, N. P. (1969). Absorption and excretion of calcium and fat by young infants. Lancet, 1, 487.

Stewart, W. K. Hutchinson, F., and Fleming, L. W. (1963). The estimation of magnesium in serum and urine by atomic absorption spectrophotometry. Fournal of Laboratory and Clinical Medicine, 61, 858.

Watney, P. J. M., Chance, G. W., Scott, P., and Thompson, J. M. (1971). Maternal factors in neonatal hypocalcaemia: a study of three ethnic groups. British Medical fournal, 2, 432.

Correspondence to Dr. G. T. Lealman, Department of Paediatrics and Child Health, University of Leeds, 27 Blundell St., Leeds LS1 3ET.

Corrigendum: In the Table on p. 146 of the article 'Two XX males diagnosed in childhood' by Laurance et al., Archives, 1976, 51, p. 144, the Xg group of the mother of Case 2 should read ' $\mathrm{Xg}(\mathrm{a}+)$ '. 